\title{
ON THE PRESERVATION OF CORNEAE AT $-196^{\circ} \mathrm{C}$. FOR FULL-THICKNESS HOMOGRAFTS IN MAN AND DOG* $\dagger$
}

\author{
BY \\ P. O'NEILL, F. O. MUELLER, AND P. D. TREVOR-ROPER \\ From the M.R.C. Ophthalmic Research Unit, Westminster Hospital, London
}

As the scope of keratoplasty has increased in the past 15 years the relative shortage of donor material has become more acute, and at present the world-wide demand for such tissue far exceeds the supply, particularly as the areas in greatest need-underdeveloped tropical and sub-tropical regions-often have socio-religious reasons which prevent donor material being obtained locally.

The problem is aggravated in the case of full-thickness grafts because success depends on a functioning endothelial layer on the donor disc (Smith, 1962), and these cells have but a short life after death of the parent body. Because the endothelium is fragile-it is adversely affected by slight mechanical trauma, changes in the $\mathrm{pH}$ of the surrounding medium, and normal saline-it does not readily lend itself to transportation over long distances at above-zero temperatures. The technique of preservation by cooling to and storage at low temperatures has provided a solution to similar problems in the preservation of other tissues (Smith, 1961). Initial attempts to preserve the full thickness of the cornea in a non-metabolic state at low temperatures were rarely successful (Smelser and Ozanics, 1946; Leigh and Ridge, 1957; Rycroft, 1955), although recent work has been more encouraging (Smith, Ashwood-Smith, and Young, 1963; Mueller and Smith, 1963; Mueller, Casey, and Trevor-Roper, 1964).

Reducing the temperature of a tissue for storage involves a change of state (both the intracellular and the intercellular fluids change from liquid to solid) and this causes damage, which can, however, be greatly reduced by freezing in a medium which contains a protective agent, generally in conjunction with a particular rate of cooling. Such protective agents are relatively non-toxic neutral solutes, of low molecular weight, which reduce the freezing points of aqueous solutions (Nash, 1962). A particular compound-dimethyl sulphoxide-has given consistently good results in preserving a variety of living tissues at low temperatures.

By using freezing media containing dimethyl sulphoxide (DMSO), methods were sought which would allow the viability of human and of canine corneal tissue to be sufficiently well preserved to ensure the clarity of full-thickness homografts from donor material which had been banked at, and thawed from, $-196^{\circ} \mathrm{C}$. The dog was chosen as an experimental animal as its corneal thickness approximates to that of man, and few surgical failures were anticipated. The whole eye was not used, as its thermal mass and heat-transfer properties are much more complex than those of a cornea with a scleral rim. The effect of the freezing medium and cooling rates on the

* Received for publication August 12, 1966.

† Address for reprints: P. O'Neill, Royal Veterinary College, Royal College St., London, N.W.1. 
viability of the tissue was assessed using a recently developed mitochondrial-assay technique and by grafting.

Reasons for the failure of some of the methods and a full description of the successful methods for cooling and banking the corneal tissue of man and dog are presented. Human corneal tissue was cooled and banked in London, using these methods, and then transported at $-196^{\circ} \mathrm{C}$. to Addis Ababa, where it was thawed and used as donor material in full-thickness keratoplastic procedures. The results have been shown as equal to those obtainable using fresh material (Mueller, O'Neill, TrevorRoper, Reiter, and Ludek, 1966).

\section{Corneal Tissue}

\section{Materials and Methods}

Dog eyes which had been enucleated within 4 hours of death and stored at $4^{\circ} \mathrm{C}$. in a moist chamber for less than 48 hours were used for freezing.

The human eyes were enucleated within 12 hours of death and stored at $4^{\circ} \mathrm{C}$. for not more than 60 hours before freezing.

The anterior segment of the eye was dissected from the remainder of the globe with scalpel and scissors, and the iris and ciliary body then removed by gentle traction. The resulting cornea with a $2-4 \mathrm{~mm}$. scleral rim was the piece of tissue used throughout.

\section{Freezing Solutions}

These were prepared immediately before use from sterile stock solutions of calf serum and Parker 199 tissue-culture medium. They were dispensed aseptically from puncture-top bottles using sterile disposable syringes and needles. The only protective agent investigated was DMSO, which was added from stock in concentrations varying from $1 \cdot 2$ to $2 \cdot 4$ Molar. It was not found necessary to sterilize it, and contamination of the solution was never encountered. For experiments above $0^{\circ} \mathrm{C}$. sterile universal bottles were used as containers, with sufficient medium $(7 \mathrm{ml}$.) to enable total immersion of the tissue without distortion.

\section{Freezing Containers}

Various glass, polythene, and polycarbonate tubes with hemispherical ends were tested, but we found these less suitable than flat-bottomed extruded aluminium tubes. ${ }^{*}$ The latter have superior heat-transfer properties, are more readily closed to give a leak-proof seal (they have a snap-on tight-fitting polythene lid), and are non-toxic. All containers have a circular cross-section. A selection of those used is shown in Fig. 1 (opposite).

\section{Freezing and Thawing}

The tissue was immersed epithelium side uppermost without trapping an air bubble in the freezing solution. The container was closed and placed in the cooling bath of the Matburn cryobiological freezer, and the preselected cooling rate was immediately begun.

This freezing machine can be programmed to cool the bath progressively at rates between 0.5 and $10.0^{\circ} \mathrm{C}$. $/ \mathrm{min}$. (This is effected by injection of amounts of methylated spirit, previously cooled by percolation over solid carbon dioxide, into the cooling bath. The rate of injection is controlled by solenoid valves which are governed by a signal from a potentiometric mechanically operated cam follower and feed-back information from a temperature transducer in the cooling bath.) This resulted in a stepwise cooling.

\footnotetext{
* Impact Extrusion "Plexicap" Containers generously supplied by The Metal Box Company Limited.
} 


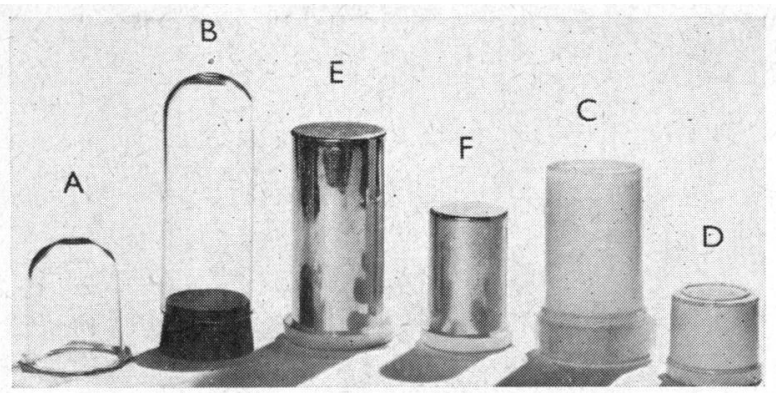

Fig. 1.-Representative selection of container types investigated. A. Heat-sealed soda glass. B. Pyrex glass. C. Polythene with screw cap. D. Thin-walled polycarbonate. E. Large extruded aluminium. F. Small extruded aluminum.

Two minutes after the bath temperature had reached $-60^{\circ} \mathrm{C}$. the specimens were directly transferred to a liquid nitrogen refrigerator and stored there in the gas phase above the liquid until required.

\section{Thawing}

The specimen container was transferred rapidly from the bank, and partially immersed in one litre of water at $55^{\circ} \mathrm{C}$. The cap was removed immediately and the container and its contents were swirled gently until all the ice had melted. The tissue was then removed with forceps and placed for $2 \mathrm{~min}$. in $8 \mathrm{ml}$. "50/50" fluid (50 per cent. Parker 199, 50 per cent. calf serum; $\mathrm{pH} 7 \cdot 0-7 \cdot 2$ ) at $4^{\circ} \mathrm{C}$. During this period the concentration of DMSO was reduced in the tissue, and the cornea was then transferred to a further $8 \mathrm{ml}$. "50/50" fluid at $4^{\circ} \mathrm{C}$. which was allowed to warm slowly to ambient temperature. No further procedures to remove DMSO were necessary.

\section{Temperature Monitoring}

The temperature was recorded on a direct-writing multichannel pen chart recorder. Four matched nickel-chromium, nickel-aluminium thermocouples giving a linear output between +20 and $-100^{\circ} \mathrm{C}$. (housed in stainless steel hypodermic needles with the sensitive point $2 \mathrm{~mm}$. above the tip of the needle) were used as temperature transducers, and were connected to the recorder through an ice-point reference junction using screened leads.

Three thermocouples were set to record from fixed points within the container; one was located at a distance of $1 \mathrm{~mm}$. from the inside wall, the second placed $\frac{1}{3}$ of the radius from the wall to the centre, the third at the centre. The sensitive points were always in a plane parallel to the surface at a distance of $\frac{1}{3}$ the total central depth from it, whatever the shape of the container bottom. The fourth thermocouple was located in the cooling bath in approximately the same plane about $1 \mathrm{~cm}$. from the outside of the container wall (Fig. $2 a$, overleaf).

When tissue was present in the container the thermocouple next to the inside skin was removed, the others being as previously placed, and the central one now recorded from within the corneal stroma (Fig. $2 b$, overleaf).

\section{Estimation of Viability}

Established histochemical methods using the ditetrazolium salt nitroblue tetrazolium for locating dehydrogenase enzyme systems (Pearse, 1960) were modified to show changes in mitrochondrial membrane permeability. This technique of ours was used to assess the 


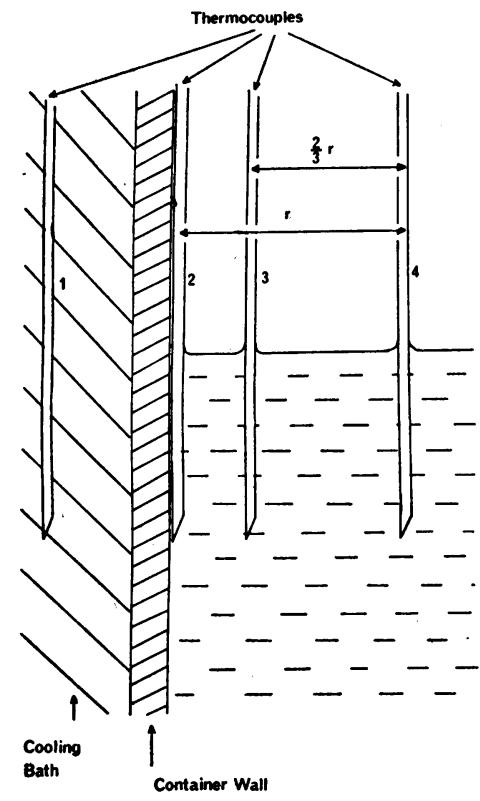

FIG. 2 (a).-Location of the four thermocouples during temperature gradient measurements when the container had an aliquot of freezing medium but no corneal tissue.

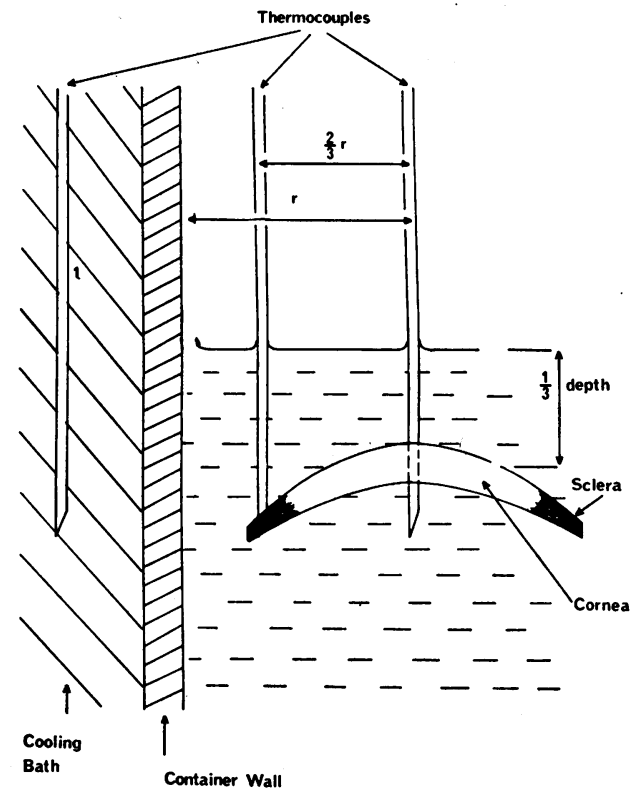

FIG. 2 (b).-The central thermocouple now records from within the corneal stroma. The thermocouple immediately inside the container has been removed.

viability of the endothelial cell layer; those cells whose entire cytoplasm showed a diffuse formazan deposit evidently had suffered irreversible damage and this sign was taken as synonymous with cell death.

The tissue for estimation was inverted over a receptacle with the endothelial concavity uppermost and $0.5 \mathrm{ml}$. of the staining medium* placed on it. The tissue was incubated for $90 \mathrm{~min}$. at $37^{\circ} \mathrm{C}$., then fixed in cold acetic alcohol ( 71 per cent. absolute ethanol, 25 per cent. glacial acetic acid, 4 per cent. water) for 8 to 16 hours. The curved surface of the endothelium was examined by reflected light with a dissecting microscope at a magnification of 30 diameters. This has been shown to give a useful assessment of the tissue and correlates well with results from parallel grafting in the dog using donor material stored at above $0^{\circ} \mathrm{C}$. for various lengths of time and after treatment with a variety of toxicants (O'Neill, 1966). No attempts were made to determine quantitatively the total amount of stain deposited, nor was the percentage of stained cells per unit area assessed. In some cases a more detailed examination of the endothelium was made. A non-permanent mount for microscope examination was prepared as follows: after fixation in acetic alcohol the scleral rim was cut away and the epithelium scraped off. Radial sections were cut with a scalpel to enable flattening of the preparation, which was mounted under a square cover-slip in a concentrated solution of polyvinylpyrolidine which forms a highly viscous water mountant. The tissue tended to curl, and spring clips or weights were used to counteract this until the mountant had set (this took $48 \mathrm{hrs}$ ). Under these conditions the cornea maintained its transparency and could be examined by transmitted light microscopy. These preparations are not optically flat but it was possible to obtain photographs of selected areas at magnifications of up to 300 diameters.

\footnotetext{
$\begin{array}{llllllll}* & \text { Sodium succinate }(0.5 \text { Molar) } & \ldots & 2 \mathrm{ml} . & \text { Polyvinylpyrolidine }(7.5 \mathrm{~g} . / 100 \mathrm{ml} .) & \ldots & 2 \mathrm{ml} . \\ \text { Nitroblue tetrazolium } & \ldots & \ldots & 10 \mathrm{mg} . & \text { Magnesium chloride }(0.005 \mathrm{Molar}) & \ldots & 2 \mathrm{ml} .\end{array}$ Phosphate buffered saline (pH 6.9-7.0) $\quad \ldots 1 \mathrm{ml}$.
} 


\section{Results \\ EFFeCt of SOlutions of DMSO ON THE CORNEAL ENDOTHELIUM}

Canine Tissue.-Fresh dog corneal tissue was incubated at $37^{\circ} \mathrm{C}$. in " $50 / 50$ " medium with varying concentrations of DMSO added. The range was from 2 per cent. (by volume) in integrals of 2 to 10 per cent. The subsequent appearance showed no difference whether the tissue was submerged in the medium, or the medium placed in the inverted segment, so for all experiments in this series the tissue was submerged in $8 \mathrm{ml}$. of the fluid. It was then washed through two changes of " $50 / 50$ " fluid to remove the DMSO before staining. Controls, using the second pair of eyes, were similarly treated, but the incubating medium contained no DMSO.

When the incubation time was $20 \mathrm{~min}$., the controls were unaffected, showing no increase in stained endothelial cells when compared with fresh untreated tissue. DMSO in a concentration of 2 per cent. and above caused an increase in the distribution density of stained cells until at 6 per cent. the whole endothelial layer was completely stained, at 8 per cent. large areas had lifted off from the stroma showing complete destruction, and no further change could be seen at higher concentrations. Shortening the incubation time to $5 \mathrm{~min}$. decreased the amount of damage only slightly.

When the tissue was similarly treated at $15^{\circ} \mathrm{C}$. for $5 \mathrm{~min}$., the amount of endothelial damage at corresponding concentrations was reduced; the initial change, when compared with the control, became apparent at 6 per cent. DMSO with complete destruction in the 14 per cent. solution. On testing the tissue at $4^{\circ} \mathrm{C}$., the pattern of increased stain with increasing DMSO was similar to that observed for the other temperatures. The same overall dependence on temperature was maintained so that a difference between the endothelium of the control and test tissue was first detectable at a concentration of 12 per cent. Higher concentrations caused an increase in the proportion of stained endothelial cells until at 20 per cent. all cells stained. In this instance a higher concentration ( 22 per cent.) was tested and it showed that areas of cells had lifted off. The results of these toxicity tests are presented in Fig. 3 (overleaf).

Material which had been incubated with 10 per cent. DMSO at 37,15 , and $4^{\circ} \mathrm{C}$. for $5 \mathrm{~min}$. was used for full-thickness keratoplasty in dogs. The grafts were $7 \mathrm{~mm}$. in diameter. All eight grafts from tissue which had been treated with DMSO at 37 and $15^{\circ} \mathrm{C}$. became opaque (see Fig. 4, overleaf), whereas grafts from tissue treated with DMSO at $4^{\circ} \mathrm{C}$. remained clear. In each group there were four animals.

The amount of damage was found almost identical when the tissue was treated with 12 per cent. DMSO at $4^{\circ} \mathrm{C}$. in a medium in which the relative concentration of calf serum was varied in nine equal steps between 6 and 86 per cent. There was a slightly greater amount of damage in the two lower concentrations (6 and 15 per cent.), while at concentrations of calf serum above 80 per cent. the addition of DMSO to the medium produced a precipitate. It was therefore decided to use the " $50 / 50$ " solution with 12 per cent. added DMSO for freezing.

Human Tissue.-The human corneal endothelium was found to be slightly more resistant to damage by DMSO at the four temperatures tested. Damage was not 
apparent after $5 \mathrm{~min}$. at $4^{\circ} \mathrm{C}$. until the concentration of DMSO reached 16 per cent. The results were otherwise similar to those found with canine corneae (Fig. 3).

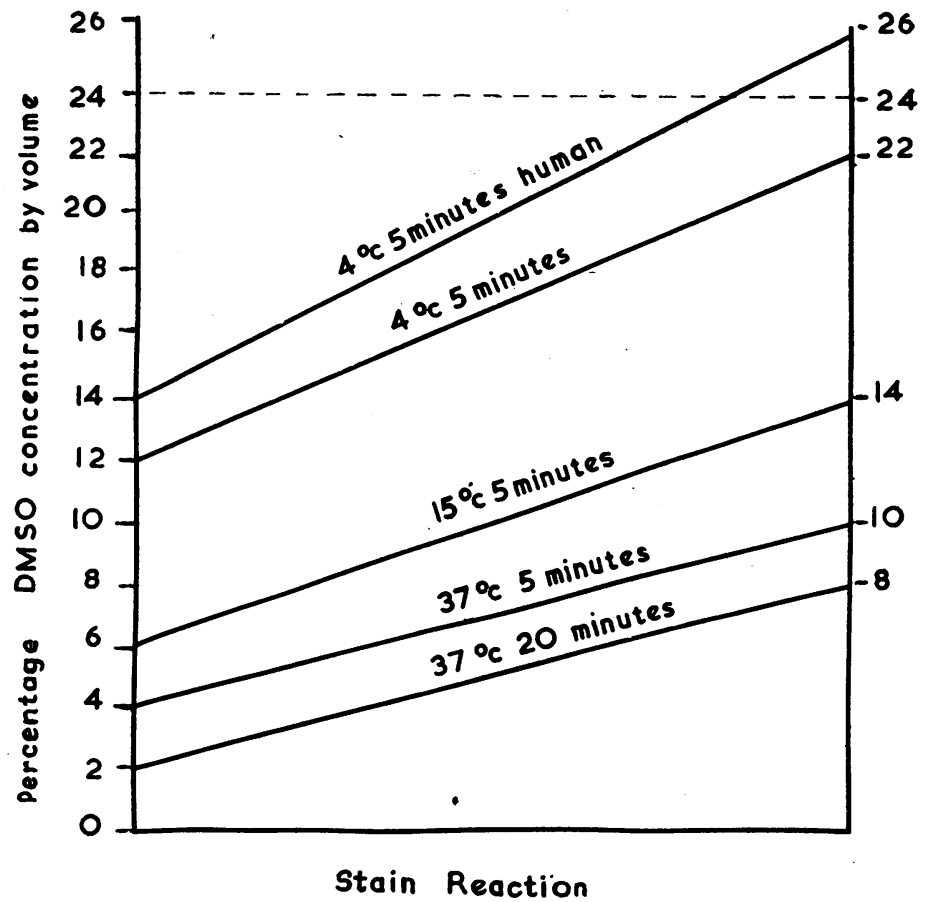

FIG. 3.-Damage caused by incubating corneal tissue with DMSO solutions at various temperatures. The amount of stain is assessed by arbitrary units and the graphs are obtained by joining the concentration showing initial damage at one temperature to the concentration showing maximum staining.

On the right-hand is the ordinate which indicates complete destruction of the cell layer. The uppermost line was derived from observations on human corneal tissue, the others from canine corneal tissue.

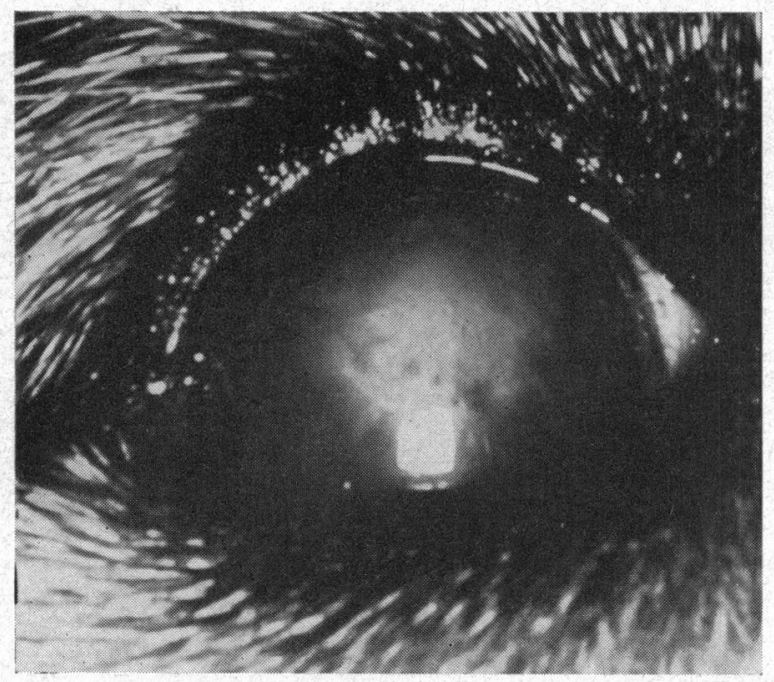

Fig. 4.-Opaque graft 10 wks postoperatively. The material transplanted was canine corneal tissue which had been incubated with 10 per cent. DMSO at $37^{\circ} \mathrm{C}$. for $5 \mathrm{~min}$. 
COOLING RATES AND CONTAINERS

Initial attempts to obtain viable tissue for corneal grafting in the dog were unsuccessful when the material was frozen in various containers using a solution of 12 per cent. DMSO, 44 per cent. calf serum, and 44 per cent. TC 199. Temperature gradients within the system were therefore investigated.

Fig. 5 shows ideal curves abstracted from a large number of tests on each of the containers $\mathrm{A}, \mathrm{B}, \mathrm{C}, \mathrm{D}, \mathrm{E}, \mathrm{F}$, in the temperature range +5 to $-25^{\circ} \mathrm{C}$. at cooling rates of $1^{\circ}, 2.5^{\circ}, 3^{\circ}, 4^{\circ}$, and $0.5^{\circ} / \mathrm{min}$. The dotted line represents the bath cooling rate and the other lines are labelled to correspond with the location of the thermocouples as shown in Fig. $2(a)$.

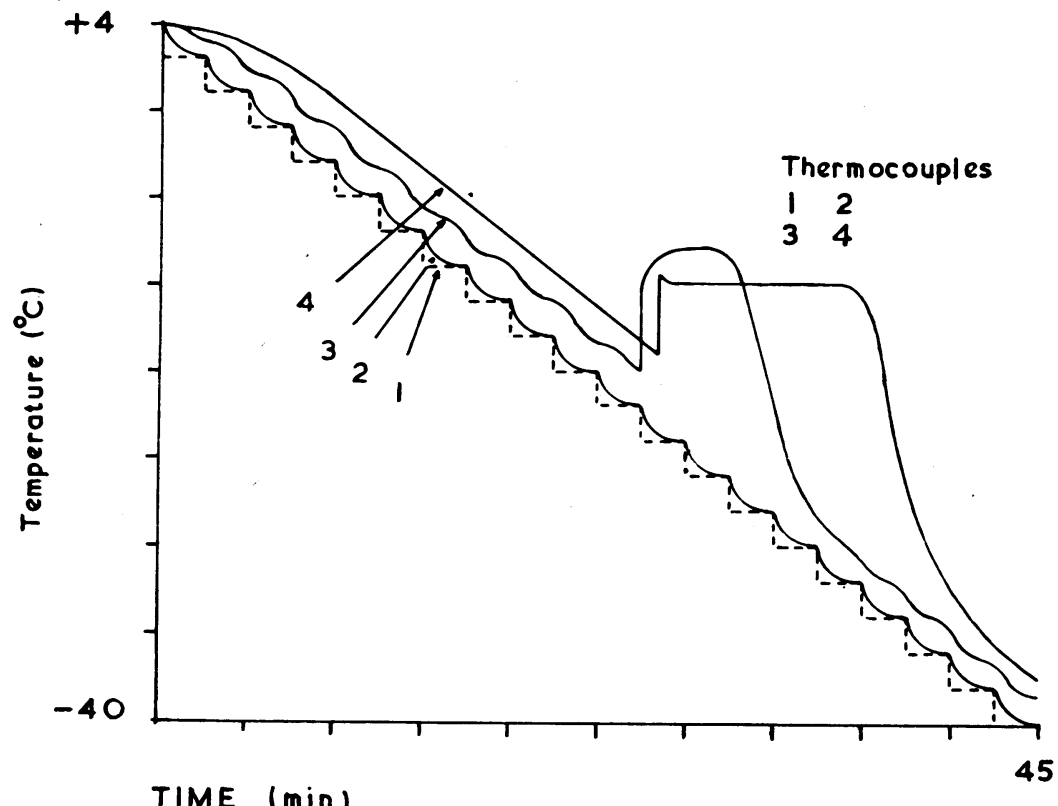

TIME (min,)

45

FIG. 5.-Rates of cooling at the points within a container shown by the location of the four thermocouples in Fig. $2(a)$. These lines are not direct reproductions of one test but show the characteristics common to all containers tested with varying volumes of medium at many rates of impressed cooling (broken line).

Originally the system was at $4^{\circ} \mathrm{C}$. throughout, but with progressive cooling of the bath the container and its contents cooled more slowly until a temperature lag was set up which was maintained more or less constant until after eight minutes all points within cooled at the same general rate as the bath. They were, however, all at different temperatures at any given instant. The temperature difference between these points was least at slow rates, and the curve (2) more faithfully follows (1) in the better conducting containers. In the poorly-conducting polythene container $\mathrm{C}$, the curve (3) was continually uniform at a temperature of $3 \cdot 2^{\circ} \mathrm{C}$. above that in the bath. In all containers the curve (2) was similar, showing the skin effect, because of its location in close proximity to the inner surface of the container wall.

The more important factor was the discrepancy between the impressed cooling rate (i.e. in the bath) and that of the medium at the onset of crystallization. Here all containers at all rates showed similar characteristics in that:

the medium supercooled, the inside thermocouple curve (2) never showed any change in the cooling rate, but both (3) and (4) had undercooling points (the sudden rise in temperature 
which occurs in a supercooled liquid at the same time as it begins to crystallize) which occurred first in the more marginal position, the centrally-placed probe following within $30 \mathrm{sec}$., to remain constant at a lower temperature for a greater length of time. During this time the temperature at position (3) was falling rapidly and eventually the temperature of the central position fell in a similar manner. When ice crystals had formed throughout the container, all curves followed the cooling rate in the bath, maintaining a temperature gradient of less magnitude than prior to the undercooling point.

The inclusion of tissue in the medium altered the cooling rate characteristics remarkably. In Fig. 6 this difference is shown when cooling the smaller aluminium container with $5 \mathrm{ml}$. freezing medium at the rates $5^{\circ}, 3^{\circ}, 1^{\circ}$, and $0.5^{\circ} / \mathrm{min}$., with and without tissue. The location of the thermocouples and the position of the corneal tissue are shown in Fig. $2(b)$. For clarity only the trace obtained from the central probe is shown in each instance, the broken line showing the result when the thermocouple was located in the corneal stroma, and the continuous line the result when no tissue was present.

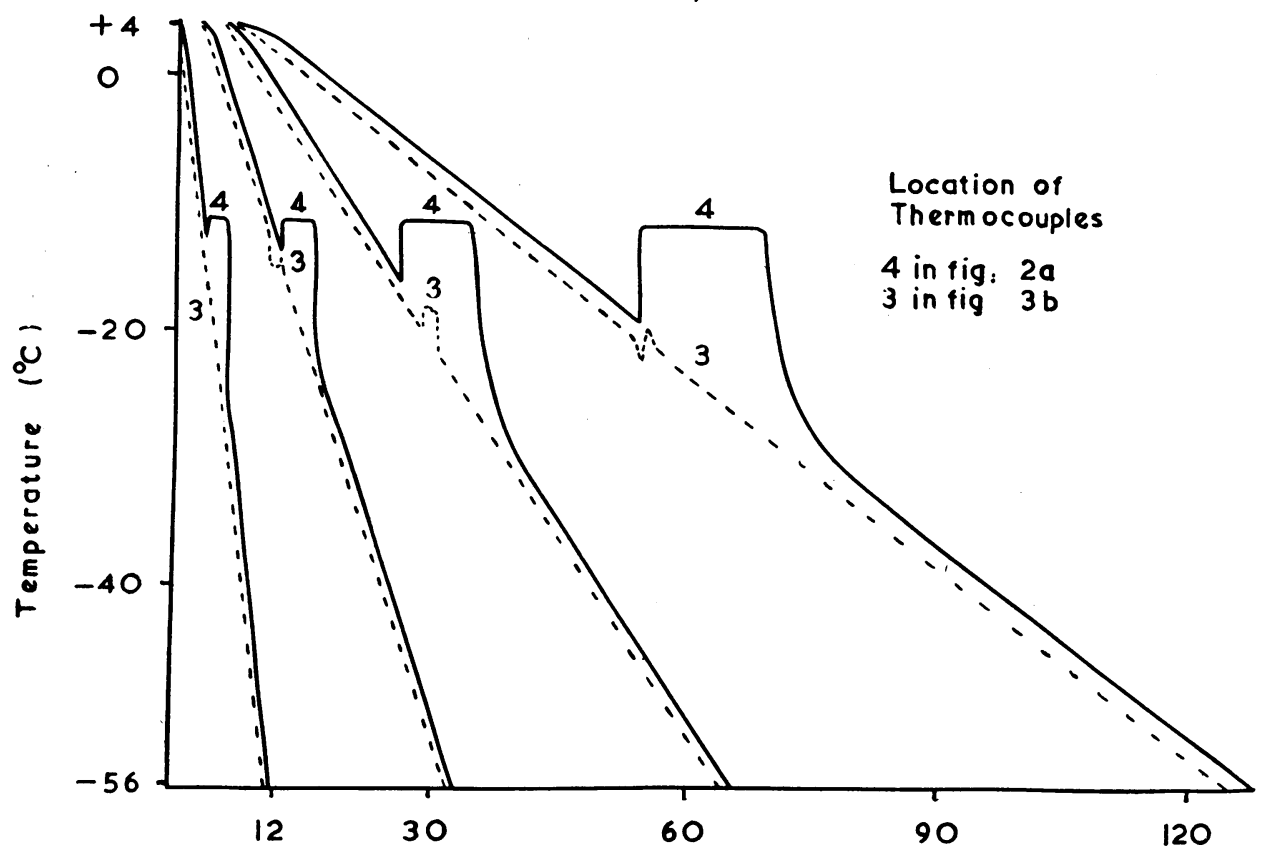

TIME (min.)

Fig. 6.-Effect of tissue on cooling rate at central thermocouple location. The rates of cooling shown are (left to right) $5^{\circ}, 3^{\circ}, 1^{\circ}$, and $0.5^{\circ} / \mathrm{min}$., when using the small aluminium container (F) with $5 \mathrm{ml}$. fluid. The rate shown by the continuous line is that when no tissue was present.

Only the two metal containers were investigated in this series. They behaved similarly; the more peripheral probe having an undercooling point regardless of whether the tissue was present or not. But when recording from the tissue, differences were sometimes shown. The traces from tissue in the large container tended to be more erratic, the temperature peak at the undercooling point was usually more pronounced, and in a small number of instances two or three undercooling points were recorded. In the small container, more than one undercooling point was never shown. Considering the differences in the dimensions of the containers-the ratio 
of the surface area to volume was 1.7 for the large container, and was $1 \cdot 3$ for the smaller-and the volumes of the medium they contained during freezing $(8$ and $5 \mathrm{ml}$. respectively), the similarity between the rates was more striking than the difference. In both containers, the trace from the central probe followed the bath cooling rate more closely when located in the corneal stroma than when no tissue was present.

\section{Canine Corneal Tissue}

\section{Change in Viability DURING FreEzing}

The tissue was prepared from pairs of eyes for each experiment, and the second removed at a lower temperature than the first, which served as a control. Both were thawed (or warmed) to $4^{\circ} \mathrm{C}$. and brought to $37^{\circ} \mathrm{C}$. after DMSO had been removed as for banked tissue. They were stained and examined for an increase in damage in the second eye when compared with the first. Only the two aluminium containers (E and F) were used. The large container with $8 \mathrm{ml}$. fluid and the smaller with $5 \mathrm{ml}$. gave similar results. The rates of cooling referred to are those occurring at the central probe position of a similar system during the same cooling cycle.

Rate: $0.5^{\circ} \mathrm{C} . / \mathrm{min}$.- There was no increase in damage at $0^{\circ} \mathrm{C}$. But there was an increase in damage at $-5^{\circ} \mathrm{C}$. and the endothelium suffered a gradual increase at -10 and $-12^{\circ} \mathrm{C}$. By the time the temperature had reached $-15^{\circ} \mathrm{C}$. (which was above the undercooling point) the amount of damage was so extensive that cooling to lower temperatures at this rate could not have increased the damage detectable by our method.

Rate: $1 \cdot 0^{\circ} \mathrm{C} . / \mathrm{min}$.- There was no damage caused until the sudden termination of supercooling and onset of freezing. The amount of damage at this undercooling point was considerable, although no damage had occurred immediately before this; the temperature was $-18^{\circ} \mathrm{C}$. at this point. There was a gradual increase in damage at the steady temperature $\left(-14^{\circ} \mathrm{C}\right.$.) and this progressed almost to complete destruction of the cell layer. (Fig. 7).

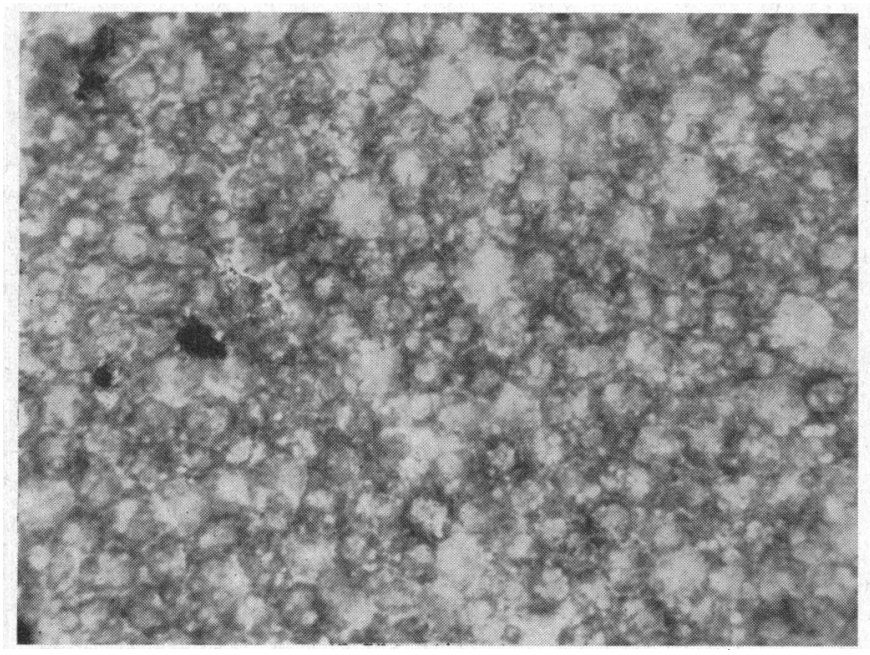

Fig. 7.-Area of flat-mounted human endothelial cells from a cornea which had been cooled to $-79^{\circ} \mathrm{C}$. at an impressed cooling rate of $1 \% \mathrm{~min}$. and thawed rapidly. The cytoplasm of all cells stains and loss of morphological details is evident. Phase contrast. $\times 250$.

Rates: 2,3 , and $4^{\circ} \mathrm{C} . / \mathrm{min}$.- The pattern of increase in damage was similar to that for the cooling bath rate of $1^{\circ} \mathrm{C}$./min. The amount of damage at the end of the 
steady temperature was less with the faster rate. The duration of this isotherm was correspondingly less, also, at this rate.

A cooling rate of $1{ }^{\circ} \mathrm{C}$. $/ \mathrm{min}$. to $-12^{\circ} \mathrm{C}$. and thereafter gradually increasing to $5^{\circ} \mathrm{C}$./min. from this point in the bath gave tissue which did not stain at $-28^{\circ} \mathrm{C}$. Such a rate (Fig. $8 b$ ) had caused some staining by $-60^{\circ} \mathrm{C}$. This was not judged as a severe amount of damage. Six eyes were frozen in this way, then thawed, and used immediately for full-thickness keratoplasty. Five of these $7 \mathrm{~mm}$. corneal grafts became and remained clear in the recipient dog eyes, one of which is shown in Fig. 9.

(a)

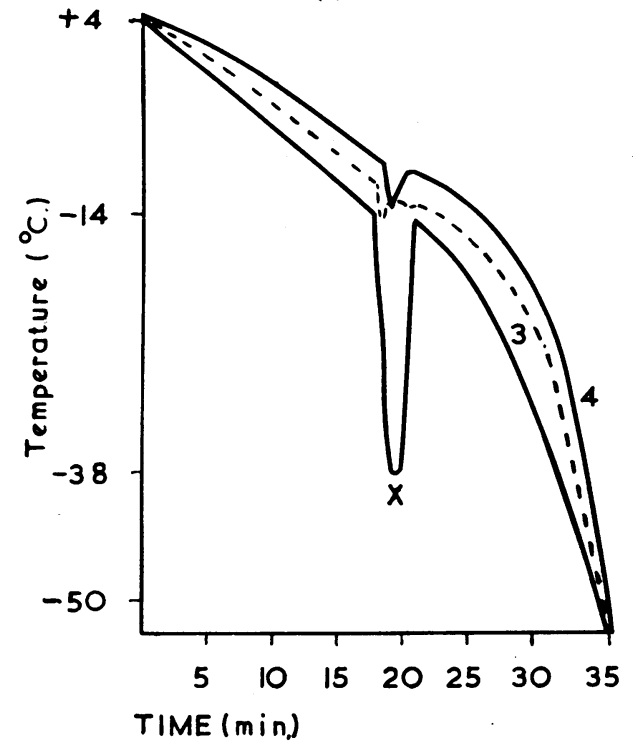

(b)

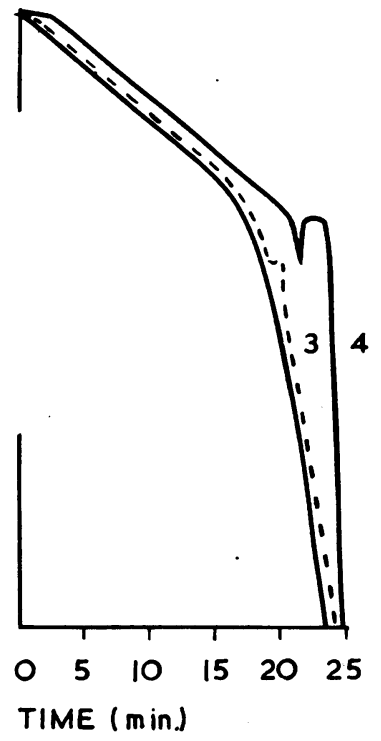

FIG. $8(a)$ and $(b)$.-Cooling rates which gave successful results when using either of the aluminium containers $(E, F)$. In each graph the lower continuous line is the impressed cooling rate $(\cdot 1$ in the bath). The other lines are labelled to correspond with the location of the thermocouples shown in Fig. $2(a$ and $b)$.

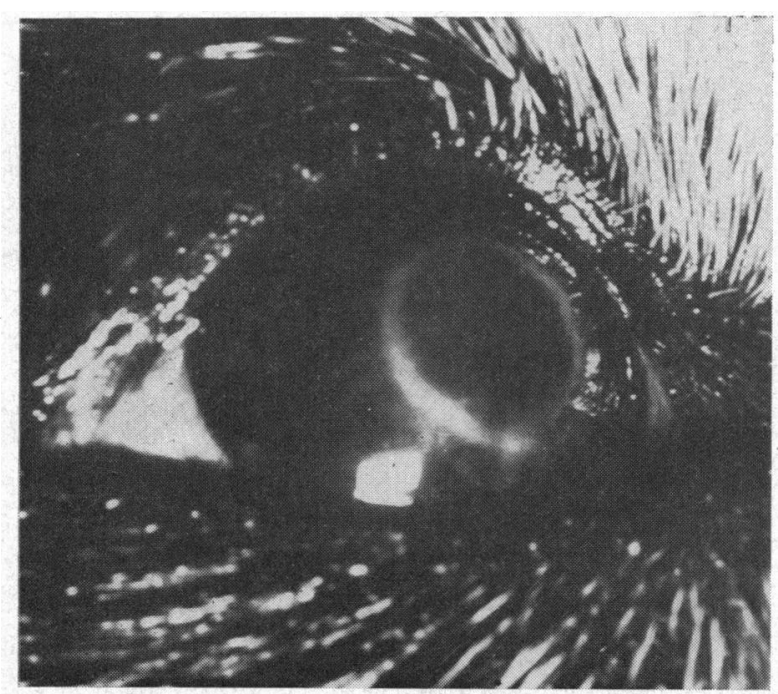

FIG. 9.-Clear graft 8 weeks postoperatively. From correctly frozen and thawed canine corneal tissue. 
A cooling rate of $1{ }^{\circ} \mathrm{C}$. $/ \mathrm{min}$. to $-12^{\circ} \mathrm{C}$, then a drop of $10^{\circ} \mathrm{C}$. $/$ min. to $-30^{\circ} \mathrm{C}$, followed by immediate warming at $20^{\circ} \mathrm{C}$. $/ \mathrm{min}$. to $-16^{\circ} \mathrm{C}$. with a gradual increase to a rate of $8^{\circ} \mathrm{C}$./min. until $-60^{\circ} \mathrm{C}$. (Fig. $8 a$ ), also gave lightly-staining tissue. Material prepared by this method was also used immediately for grafting and in this instance six clear grafts in a series of six showed such tissue to be viable.

These two freezing curves are shown in Fig. $8(a$ and $b)$, with typical associated temperature changes within the tissue during cooling at these rates. These two curves are similar. Curve $8(a)$ was designed to reduce the tendency to supercool in the freezing medium, to shorten the duration of the isotherm for the central probe by increasing the rate of heat withdrawal from the container at this stage, without allowing a precipitous drop in temperature after this point. Curve $8(b)$ was expected to give failing results, and when it gave the then surprisingly successful results, its temperature gradients in both cases with and without tissue were investigated. Both curves differed from the single rate curves in that no undercooling point was recorded from the central probe although it was from the peripheral one when cooling without tissue; with tissue the cooling rate at the central point and the peripheral point were similar in the small container, neither showing an undercooling point. The cooling rate $8(a)$ caused a dip in the peripheral region above the point " $\mathrm{X}$ " but did not affect the central position. In the large container, no dip was recorded, but with the rate $8(b)$ the peripheral probe showed an undercooling point.

\section{Human Corneal Tissue}

In these experiments the freezing solution chosen was 14 per cent. DMSO, 43 per cent. calf serum, 43 per cent. TC 199 . The procedure for estimation of viability was the same as that used for the canine material and similar results were obtained. The damage during cooling occurred at the same points for the cooling curve; and curves $8(a)$ and $8(b)$ both gave lightly-stained tissue when the viability of the endothelium was estimated after thawing from $-60^{\circ} \mathrm{C}$. The relative damage when compared with dog corneae which had been similarly treated appeared less. The damage to the endothelial cells caused by cooling at $0.5^{\circ} \mathrm{C} . / \mathrm{min}$. to $-15^{\circ} \mathrm{C}$. was noticeably less, which would indicate that this damage was due to the duration in contact with DMSO solutions rather than the actual rate of cooling.

When human corneal tissue, frozen at the rates of $8(a)$ and $8(b)$ in either of the aluminium containers, was used as donor material for full-thickness keratoplasty, clear grafts were obtained showing that the tissue was viable (Mueller and others, 1966). Some of these grafts were from tissue which had been stored for as long as 6 weeks at $-196^{\circ} \mathrm{C}$. in a liquid nitrogen refrigerator (LR-36 Linde Division Union Carbide). The results of this series are shown briefly in the Table (overleaf).

\section{Discussion}

At body temperature the biochemical and physical reactions in viable tissue are in a state of dynamic equilibrium. Lowering the temperature to $4^{\circ} \mathrm{C}$. causes the rates of the energy-linked reactions to decrease while the rates of the physical processes, such as diffusion of potassium ions out of cells, are relatively unchanged. Because of the state of disequilibrium, storage of tissue at this temperature does not preserve the viability for more than a few days. Reducing the temperature to below $-150^{\circ} \mathrm{C}$. 
TABLE

Results of Grafting Stored Human Donor Material

\begin{tabular}{|c|c|c|c|c|c|}
\hline $\begin{array}{l}\text { Material } \\
\text { Number }\end{array}$ & $\begin{array}{c}\text { Storage Time } \\
\text { (days) }\end{array}$ & $\begin{array}{c}\text { Size of } \\
\text { Graft }\end{array}$ & Cooling Rate/Container & Result & Comment \\
\hline $\begin{array}{l}\mathbf{H}_{5} \\
\mathbf{H}_{7} \\
\mathbf{H}_{3} \\
\mathbf{H}_{1}\end{array}$ & $\begin{array}{l}18 \\
17 \\
15 \\
17\end{array}$ & $\begin{array}{l}6 \mathrm{~mm} \\
7 \mathrm{~mm} \\
7 \mathrm{~mm} \\
6 \mathrm{~mm}\end{array}$ & $\begin{array}{l}F_{1}-\text { Large } \\
F_{1} \text { - Large } \\
F_{1} \text { - Large } \\
F_{1}-\text { Large }\end{array}$ & $\begin{array}{l}\text { Success } \\
\text { Success } \\
\text { Success } \\
\text { Success }\end{array}$ & \\
\hline $\begin{array}{l}\mathbf{H}_{9} \\
\mathbf{H}_{11} \\
\mathbf{H}_{13} \\
\mathbf{H}_{15}\end{array}$ & $\begin{array}{l}23 \\
18 \\
23 \\
26\end{array}$ & $\begin{array}{l}7 \mathrm{~mm} \\
7 \mathrm{~mm} \\
6 \mathrm{~mm} \\
8 \mathrm{~mm}\end{array}$ & $\begin{array}{l}F_{1}-\text { Small } \\
F_{1}-\text { Small } \\
F_{1}-\text { Small } \\
F_{1}-\text { Small }\end{array}$ & $\begin{array}{c}\text { Success } \\
\text { Success } \\
\text { Success } \\
\text { Partial Failure }\end{array}$ & Large Graft \\
\hline $\begin{array}{l}C_{1} \\
C_{3} \\
C_{5} \\
C_{7} \\
C_{10}\end{array}$ & $\begin{array}{l}27 \\
27 \\
28 \\
30 \\
24\end{array}$ & $\begin{array}{l}7 \mathrm{~mm} \\
8 \mathrm{~mm} \\
7 \mathrm{~mm} \\
7 \mathrm{~mm} \\
7 \mathrm{~mm}\end{array}$ & $\begin{array}{l}\mathbf{F}_{2}-\text { Large } \\
\mathbf{F}_{2}-\text { Large } \\
\mathbf{F}_{2}-\text { Large } \\
\mathbf{F}_{2}-\text { Large } \\
\mathbf{F}_{2}-\text { Large }\end{array}$ & $\begin{array}{l}\text { Success } \\
\text { Failure } \\
\text { Success } \\
\text { Success } \\
\text { Success }\end{array}$ & Liquid Paraffin \\
\hline $\begin{array}{l}\mathbf{C}_{2} \\
\mathbf{C}_{4} \\
\mathbf{C}_{6} \\
\mathbf{C}_{8} \\
\mathbf{C}_{9} \\
\mathbf{C}_{11}\end{array}$ & $\begin{array}{l}33 \\
25 \\
32 \\
37 \\
37 \\
35\end{array}$ & $\begin{array}{l}7 \mathrm{~mm} \\
7 \mathrm{~mm} \\
7 \mathrm{~mm} \\
9 \mathrm{~mm} \\
7 \mathrm{~mm} \\
6 \mathrm{~mm}\end{array}$ & $\begin{array}{l}\mathbf{F}_{2}-\text { Small } \\
\mathbf{F}_{2}-\text { Small } \\
\mathbf{F}_{2}-\text { Small } \\
\mathbf{F}_{2}-\text { Small } \\
\mathbf{F}_{2}-\text { Small } \\
\mathbf{F}_{2}-\text { Small }\end{array}$ & $\begin{array}{c}\text { Success } \\
\text { Success } \\
\text { Failure } \\
\text { Partial Failure } \\
\text { Success } \\
\text { Success }\end{array}$ & $\begin{array}{l}\text { Liquid Paraffin } \\
\text { Large Graft }\end{array}$ \\
\hline
\end{tabular}

Note: This Table shows the pertinent details of the cooling rate and container (see Figs $2(a$ and $b)$ and $8(a$ and $b)$ ) used for preparing this tissue. The two "Partial Failures" are not due to endothelial failure of the donor disc, as severe oedema was not observed in their postoperative follow-up and they are in fact clear in some areas. "Liquid Paraffin" denotes that these corneae had been stored in liquid paraffin at $+4^{\circ} \mathrm{C}$. between enucleation and freezing. They were not a pair and are the only transplants which showed the classical postoperative behaviour of non-functioning endothelium.

causes a great decrease in the rates of the physical reactions, probably because little fluid remains and because molecular movements are slowed. As a result, it is possible to store tissue with remarkably little deterioration or loss of viability at these low temperatures.

Cooling physiological solutions to very low temperatures involves a change of state; as cooling progresses, water is progressively removed in the form of ice, with a corresponding increase in solute concentration; at lower temperatures the dissolved solutes will be precipitated from solution. Such changes in the concentration of tissue fluid will be accompanied by changes in $\mathrm{pH}$ and osmolarity. The combined effects of the changes in these parameters is to cause the destruction of the cellular integrity accompanied by complete loss of function (Lovelock, $1953 a, b$ ).

Glycerol, pyridine-N-oxide, ethylene glycol and dimethyl formamide are among the hydrophilic neutral solutes found effective in protecting the various cells and bacteria against freezing damage (Smith, 1961). The most effective protective compound so far known is DMSO. This is probably because of its low toxicity and ability to penetrate cell membranes rapidly. All these compounds exert their protective action by decreasing the rate of ice formation and keeping salts and other substances in solution at lower temperatures. When any of these compounds is included in the medium containing the tissue to be frozen, the changes in solute concentration during freezing are greatly reduced in magnitude, occur at much lower 
temperatures, with a correspondingly lessened effect on the cell viability (Farrant, 1965). The added protective agent is a solute of the system and its relative concentration will also increase as the water crystallizes. In general, the optimum concentration of protective agent will be governed by the ability of the cells to withstand a hypertonic medium and the toxic effect of the agent on the cells. The rate of cooling for a particular freezing medium will depend on the ability of the tissue to withstand temperature gradients. Within these limits, high (1.0-3.0 Molar) concentrations of the protective agent and slow $\left(<10^{\circ} \mathrm{C}\right.$. $/ \mathrm{min}$.) cooling rates have so far given the best results.

The corneal endothelium of man and dog show a low toleration to DMSO. Prolonging the contact time with media containing DMSO at temperatures above freezing increases the injury to the cells. This toxic quality might be the cause of the faint overall staining of the endothelium noticed after thawing tissue which had been frozen by the best available methods (Fig. 10). This damage occurs between -35 and $-50^{\circ} \mathrm{C}$. in both human and canine tissue and in this temperature range the concentration of DMSO in the liquid phase increases from 3.67 to 6.58 Molar. Such an increase in staining reaction might also be caused by a change in membrane permeability due to dissociation of the lipid-protein complex of the membrane as suggested by Lovelock (1957), who showed that dissociation of $\beta$-lipoprotein occurs in this temperature range; he attributed this to the removal of the last traces of solvent water from the system when glycerol was the protective agent.

Fig. 10.-Area of flat-mounted human endothelial cells from a cornea $\left(\mathrm{H}_{13}\right)$ which had been cooled and thawed corrrectly. A central $6 \mathrm{~mm}$. disc cut from the same cornea gave a clear graft on transplantation. Faint staining of all cells is shown, but the nuclei are normal. Phase contrast. $\times 250$.

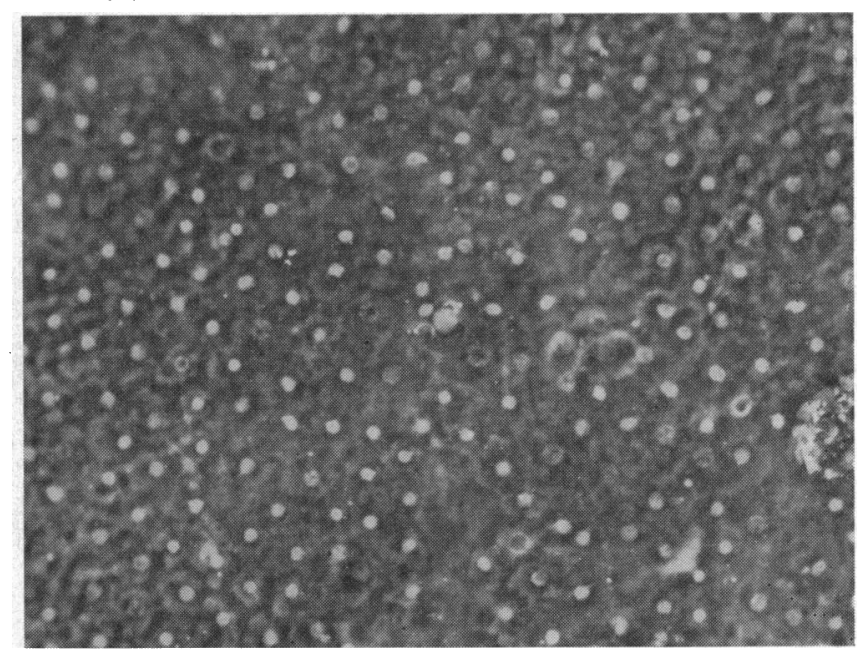

Analysis of the freezing rates shows the importance of the heat exchange properties of the cooling system. Although the volume of alcohol and carbon dioxide in the freezing bath was 3 litres, the temperature within the container did not reach equilibrium with the bath during cooling; even at the very slow rate of $0.5^{\circ} \mathrm{C} . / \mathrm{min}$. there was a measurable temperature gradient across the container. In the progressive cooling of such a system certain facts are well known: that freezing begins on the inside wall of the container; that there is a steep gradient from the liquid/solid boundary to the external cooling bath; and that the remaining liquid equilibrates at the freezing point in advance of the arrival of the freezing boundary (Meryman, 1957). The curves in Fig. 5 show that, because of this gradient, the undercooling 
point occurred first at the periphery, that ice and supercooled liquid were present simultaneously in different parts of the system, and that the freezing point differed throughout the medium! These phenomena can be explained by considering that the initial precipitate of ice formed on the inside of the container wall "pushes" some DMSO centrally. A new system now exists where the new solution is relatively more concentrated in DMSO and the new container for this solution is the metal container plus the newly-formed ice shelf. This procedure is repeated until all ice crystals have been formed throughout the whole container when some liquid remains dispersed between the solid.

This hypothesis is supported by experimental evidence. Samples of liquid from the central pool were taken and measured for DMSO content as the liquid/solid boundary progressed centrally. There was a continuous increase in DMSO concentration as the volume of the pool decreased. This increase finally reached a value 25 per cent. higher than the initial concentration. The concentration of DMSO was estimated by a 0 to 28 per cent. Sugar Pocket Refractometer which required only one drop of liquid for a reading and allowed a succession of readings to be taken within seconds of each other. Care was taken to ensure that at the time of reading the temperature of the sample was $18 \pm 2^{\circ} \mathrm{C}$. and the concentration of DMSO was found to within 1 per cent. by volume, by comparing with a calibration curve previously prepared from the refractive indices of standard solutions of DMSO in " $50 / 50$ ". This method gave results sufficiently accurate for the purposes of the experiment.

These phenomena, though interesting, are not necessarily applicable when considering a system which contains tissue. The tissue introduces further thermal barriers, and, the difference between the cooling rate at the central probe without tissue and when tissue is present (Fig. 8) shows that the cornea is a better heat transfer agent than the volume of medium it displaces. The actual rate of temperature change across the endothelial surface could not be measured and it is apparent that it cannot be assumed to be the same cooling rate as that of any probe, regardless of the location of that probe. The results indicate that different areas of this surface cool at different rates.

The use of different impressed cooling rates, $8(a)$ and $8(b)$, with different resultant rates of cooling at the centre of the stroma to prepare the tissue for storage shows that the viability is not critically dependent on the rate of cooling (the results of grafting such tissue are shown in the Table and amply demonstrate this fact). However, the effect of spatial variations in the rate of cooling and in the DMSO concentration could be of importance in the preparation of tissue to be used later for a corneal transplant. The distribution of any non-functional endothelial cells in the donor disc is at least as important as their number, for if all the dead cells were located in one small area, a localized swelling of the stroma would probably result and impair the visual acuity, whereas a scattered distribution of an equal number of non-viable cells might merely cause a diffuse lack of clarity which should clear.

The particular method we employed for assessing the endothelial viability is one which allows the spatial distribution of non-viable cells to be examined (Fig. 11, opposite). Patterns where the cells had lost viability in a localized area were detected only when the cornea was placed epithelium side down in the container. In these instances the cells in the central area (at the apex of the curve) were much more heavily 
stained than the surrounding cells. It was observed during thawing that the tissue in these cases floated while some ice remained in the concavity and complete thawing was less rapid, taking about 50 per cent. more time $\left(3 \mathrm{~min}\right.$.) to warm from $-196^{\circ} \mathrm{C}$. than where the epithelium faced upwards $(110 \mathrm{sec}$.). The injury to the central area is attributed to the slower thawing as it has been established for many tissues that fast thawing rates are desirable (Billingham and Medawar, 1952). An example of the effect of slow thawing on the endothelium is shown in Fig. 12.

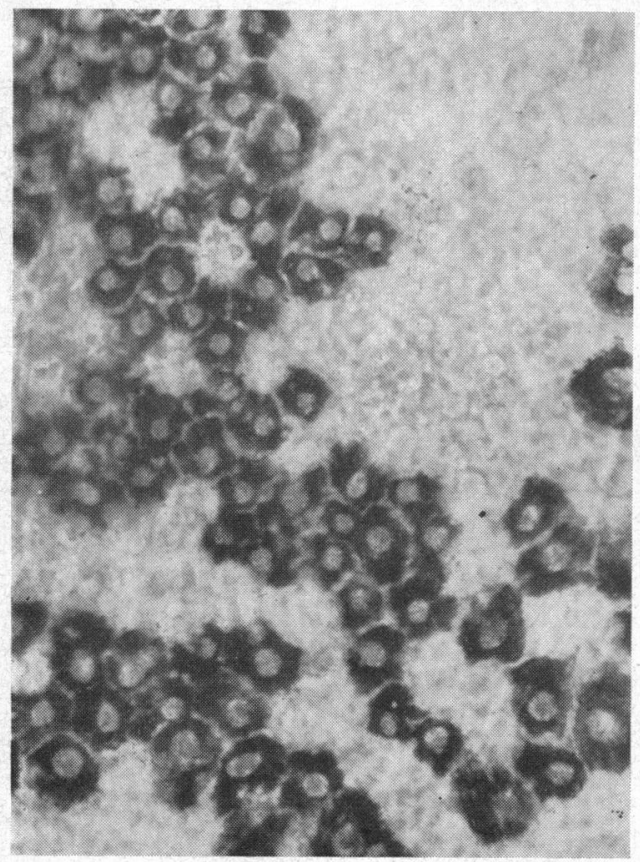

Fig. 11.-Area of flat-mounted human endothelial cells from a cornea which had been in contact with 10 per cent. DMSO at $15^{\circ} \mathrm{C}$. for $5 \mathrm{~min}$. The cytoplasm of the dead cells is diffused with the diformazan of nitroblue tetrazolium. Live cells are also visible. Phase contrast. $\times 250$.

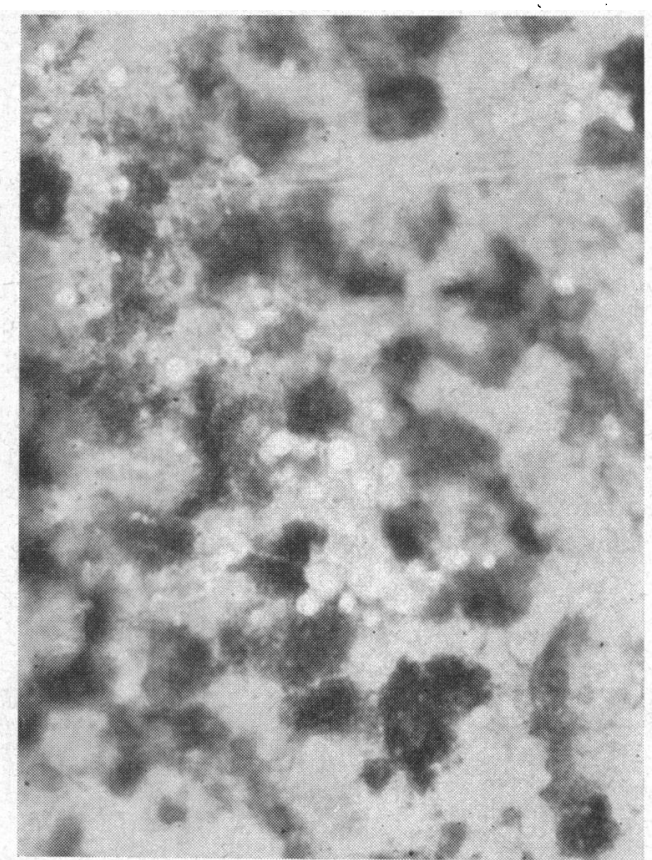

Fig. 12.-Area of flat-mounted human endothelial cells from a cornea which had been cooled at the correct rate but allowed to warm slowly to room temperature (in a liquid nitrogen refrigerator which had been without coolant for 18 days). Although there is complete loss of cellular integrity, enzyme activity is evident. Phase contrast. $\times 250$.

NOTE: For photographic purposes it was necessary to vary the exposures and alter the degree of contrast of these prints. The intensity of the shades does not reflect the degree of staining and the four photographs shown in Figs 7, 10, 11, and 12 are not directly comparable.

Where the tissue had been frozen with the epithelium up selective areas of damage were not found. From this consideration and from the evidence of cell damage which occurred at the unfavourable rates, it can be concluded that damage to the endothelial layer is avoided by employing any rate of cooling which would avoid both a long duration of time at temperatures above crystallization and a slow progress of the freezing boundary towards the centre of the container. Where these precautions were not taken damage by exposure to DMSO resulted.

When corneal tissue had been frozen by the better methods and thawed rapidly, the functional results when transplanted were encouraging. In both man and dog there appeared to be a slight delay before the frozen grafts became clear. A lag phase before resumption of normal function of frozen and thawed cells and tissues has often 
been reported previously (Lovelock, 1953b; Parkes, 1957). Apart from slower clearing, the results of grafting frozen corneal tissue compare favourably with those when fresh untreated tissue had been used. They are better than those obtained by the use of corneae stored for more than $72 \mathrm{hrs}$ at $+4^{\circ} \mathrm{C}$. The material used for grafting had not been preselected in any way with regard to age of donor or cause of death. Two of the four unsuccessful grafts in the human series (Table) have one factor in common: the eyes were stored in liquid paraffin between enucleation and freezing. Until further evidence is available, it is felt that eyes selected for low temperature storage and subsequent grafting should not be immersed in liquid paraffin. Apart from this consideration, any eye which is suitable for grafting is also suitable for low temperature preservation.

It is generally accepted that lower temperatures are desirable for storage. While the physical reactions of diffusion and crystal growth are known to take place at measurable rates at above $-100^{\circ} \mathrm{C}$. they are not thought to occur below $-150^{\circ} \mathrm{C}$. (Meryman and Kafig, 1955). However, no deterioration was found in corneal tissue stored in a carbon dioxide refrigerator at $-79^{\circ} \mathrm{C}$. for up to 25 days, although it was shown by measuring the $\mathrm{pH}$ of the freezing solution after thawing that this changed from $\mathrm{pH} 7 \cdot 4-4 \cdot 8$ within the first 2 days of storage, when using the aluminium containers. The permeability to carbon dioxide gas of the polythene caps is of the order $9 \times 10 \mathrm{~cm}$. $/ \mathrm{hr}$ at $30^{\circ} \mathrm{C}$. and 1 atmosphere pressure and will account for such a change. Storage in a liquid nitrogen refrigerator at $-196^{\circ} \mathrm{C}$. was found to be more convenient provided that the specimen containers - which might leak - are not totally immersed in the liquid, as the samples are more readily located and handled from such a bank.

It is concluded that banking at low temperatures is an excellent method of conserving donor material suitable for subsequent use in full-thickness keratoplastic procedures. The methods described have not as yet been adopted for use in ophthalmic departments of general hospitals. For instance, the tissue culture fluid is a carbonate buffer, and so stock solutions cannot be prepared in large quantities. The cooling rates are difficult to control unless the machinery used is expensive and even then experience and care are necessary if a reliable bank of corneal tissue is to be built up. Further studies, which it is hoped will provide a routine method for freezing human corneal donor material, are in progress. Initial results indicate that a lower concentration of DMSO or some other more suitable protective agent and perhaps a more stable buffer might give consistently reliable results after using a semi-automatic method to freeze the corneal tissue. The eventual object is to evolve a reproducible routine method which would require a minimum of attention so that eye banks could be established wherever needed and run by technicians.

\section{Summary}

Dog and human corneal tissue was cooled to $-60^{\circ} \mathrm{C}$. at controlled rates by placing the cornea with its scleral rim in a buffered tissue-culture medium containing 12 and 14 per cent. DMSO respectively. Extruded aluminium containers were used because of their superior heat-transfer properties, and after banking the specimens in a 
liquid nitrogen refrigerator at $-196^{\circ} \mathrm{C}$. the tissue was thawed rapidly and used for full-thickness corneal homografts. Excellent results were obtained provided that the corneae were not in contact with solutions containing DMSO at a temperature above $0^{\circ} \mathrm{C}$. for any length of time, and that a fast rate of removal of heat from the specimen container was maintained during crystallization of the freezing medium.

After treating the tissue with medium containing DMSO in concentration between 2 and 26 per cent. by volume at above-zero temperatures, and after freezing at various rates, the viability of the corneal endothelium was assessed both by using nitroblue tetrazolium to indicate the permeability of the mitochondrial membranes of these cells, and by using similarly-treated canine tissue as donor material for fullthickness homografts. The results obtained by staining show that DMSO in a sufficient concentration to prevent freezing damage is somewhat toxic at above-zero temperatures, that the tissue and freezing solution should be separately cooled to at least $+4^{\circ} \mathrm{C}$. before freezing, and that the overall rate of cooling during freezing should be in excess of $1^{\circ} \mathrm{C}$./min. The post-operative behaviour of the full-thickness grafts was in accordance with these findings, because when the corresponding tissue stained heavily the graft failed to clear.

Human corneal tissue was cooled by these methods to $-60^{\circ} \mathrm{C}$. and then transferred to a liquid nitrogen storage vessel $; \cdot 23$ corneae were transported at $-196^{\circ} \mathrm{C}$. from London to Addis Ababa and used there (after 4 weeks' preservation) as donor material for full-thickness keratoplastic procedures in man. Nineteen of the 23 were used, and fifteen grafts have completely cleared. Of the other four grafts, the failure of two can be attributed to the large diameter of the transplant.

It is concluded that the distribution and effective supply of corneal donor material for full-thickness grafts can be increased by using these methods to preserve the viability of the corneal endothelium.

This research was rendered possible through the generosity of the Medical Research Council, who established our Research Unit within the Ophthalmic Department at Westminster Hospital. We are particularly grateful to Prof. E. C. Amoroso, F.R.S., who housed our project at the Royal Veterinary College, and to the staff of the college who cared for our animals and provided us with donor material.

We are indebted to Dr. P. Hansell and his staff of the Medical Illustration Department of the Westminster Medical School; to the staff of the Pharmacy of the Westminster Hospital, in particular Mr. Barrett, for their constant help; also to the staff of the Moorfields-Westminster Eye-Bank for providing the human donor material and to Mr. Wilson of the Postgraduate Medical School for supplying much of the canine tissue: and to Mr. Houlihan of Union Carbide who provided us with liquid nitrogen storage vessels, tissue banks, and biological transporters. Mr. Martin Price and Miss E. D. Nightingale gave technical help, for which we are grateful.

It is a pleasure to acknowledge the help of Dr. Audrey U. Smith whose continued encouragement was our source of inspiration.

\section{REFERENCES}

Billingham, R. E., and Medawar, P. B. (1952). J. exp. Biol., 29, 454.

Draheim, J., McPherson, S. D., Evans, V. J., and Earle, W. R. (1957). Amer. J. Ophthal., 44, 6/10, no. 4 [Oct.], pt 2, p. 182.

FARrant, J. (1965). Nature (Lond.), 205, 1284.

LeIGH, A. G., and RIDGE, J. W. (1957). Trans. ophthal. Soc. U.K., 77, 367.

Lovelock, J. E. (1953a). Biochim. biophys. Acta, 10, 414.

- (1953b). Ibid., 11, 28.

(1957). Proc. roy. Soc. B., $147,427$.

MERYMAN, H. T. (1957). Ibid., 147, 452. and Kafig, E. (1955). Res. Rep. Nav. med. Res. Inst. (Bethesda, Maryland), 13, 529. 
Mueller, F. O., Casey, T. A., and Trevor-Roper, P. D. (1964). Brit. med. J., 2, 473. , O'Neill, P., Trevor-Roper, P. D., Reiter, H., and Ludek, R. (1966). Ibid., 2, 17. and Smith, A. U. (1963). Exp. Eye Res., 2, 237.

NASH, T. (1962). J. gen. Physiol., 46, 167.

O’NeILl, P. (1966). For publication.

Parkes, A. S. (1957). Proc. roy. Soc. B., 147, 520.

PeArSe, A. G. E. (1960). "Histochemistry-Theoretical and Applied", 2nd ed., p. 582. Churchill, London. Rycroft, B. W. (1955). " “Corneal Grafts”. Butterworth, London.

Smelser, G. K., and Ozanics, V. (1946). Proc. Soc. exp. Biol. (N.Y.), 62, 274.

SмiтH, A. U. (1961). "Biological Effects of Freezing and Supercooling". Arnold, London. (1962). Int. ophthal. Clin., $2,731$.

Ashwood-Smith, M. J., and Young, M. R. (1963). Exp. Eye Res., 2, 71. 